\title{
X. On an improvement in the air-pump
}

\section{Rev. J. Park}

To cite this article: Rev. J. Park (1841) X. On an improvement in the air-pump, Philosophical Magazine Series 3, 19:121, 59-60, DOI: 10.1080/14786444108650365

To link to this article: http://dx.doi.org/10.1080/14786444108650365

册 Published online: 01 Jun 2009.

Submit your article to this journal 준

LII Article views: 2

Q View related articles $₫$ 


\section{[ 59 9 $]$}

X. On an Improvement in the Air-Pump. By the Rev. J. Park.

To the Editors of the Philosophical Magazine and Journal. Genticemen,

YOU will oblige me by inserting in your Journal the fol1 lowing brief description of an improvement in the construction of the air-pump.

A model in my possession works very satisfactorily; but, from want of opportunity, I have not been able to compare its efficiency with other instruments already in use. It consists of a barrel or cylinder of iron truly bored and polished. To this cylinder is accurately fitted a case-hardened iron piston, in the usual manner, the piston-rod working at the upper end through a collar of oiled leathers, perfectly air-tight. At a
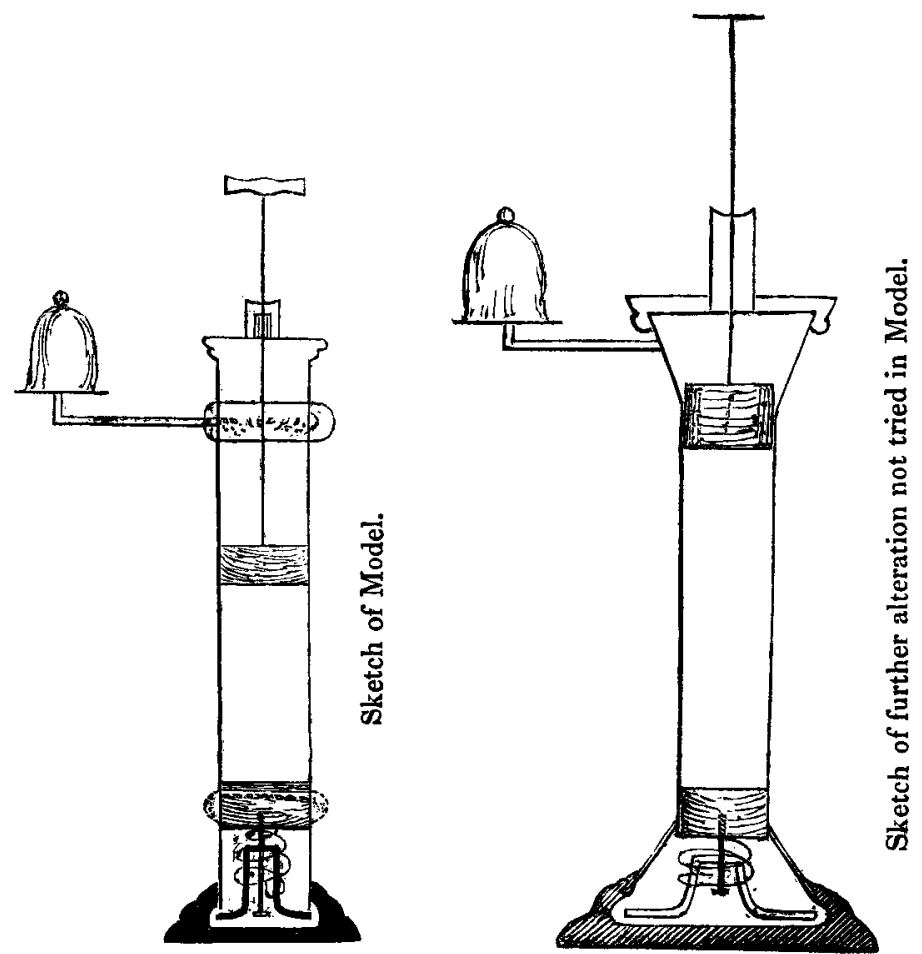

distance from each end, exceeding a little the length of the piston, are a number of very small apertures, for the admission and egress of the air. At the lower end is another accurately fitted metallic plug, the end of which is perfectly flat, 
as is the end of the working piston, so that when the latter is forced down, there is no residuum of air left in the barrel at the end of the stroke, between the pistons. There is also a spring to keep the pistons in close connexion till the upper one has returned a little past the openings, by which the air is forced out, a little above which openings the lower plug is retained by a stay coming against the end of the cylinder.

It has been objected that, though the model works well at first, the metallic piston will soon wear, and then the instrument will become inefficient. This may be obviated, I conceive, by making the apertures very small, and by using pistons packed or covered with some elastic material, as Indiarubber, which would easily pass and repass the openings without tearing or injuring the packing. But in order to dispense with the apertures, and to avoid any objection that might be taken to the use of elastic packing on account of them, it has occurred to me, that the upper and lower ends of the cylinder might be made a little wider than the rest of the barrel, for the inlet and escape of the air. In this case, however, the piston rods would require longer collars to serve as guides, that the pistons might come truly into that part where they fit tight to the cylinder.

I am, Gentlemen, your obedient servant,

Ulverstone, Lancashire, March 13, 1841.

J. Park.

XI. On Mr. J. Scott Russell's Remarks on the Temperature of most effective Condensation (of Steam). By W. J. Henwood, Esq., C.E., F.R.S., F.G.S., Secretary of the Royal Geological Society of Corntoall, \&c.

Sir,

To Richard Taylor, Esq., F.L.S., \&.c.

7HE article "Steam Navigation" in the Encyclopadia 1 Britannica (xx. p. 697), from the able hand of Mr. J. Scott Russell, contains the following remark:-

"It does not appear to be known that a vacuum may be too good. We hear it boasted every day by rival engineers that their engines have the best vacuum. Some boast their vacuum at 27 inches, others at 28 , others at 29 , some at 30 , and at last an engineer appears who boasts a vacuum of $30 \frac{1}{2}$ inches. It is to be regretted that time and talent should be thus wasted. It is a fact of great importance, confirmed by experiment and by practice, that a vacuum may be too good, and become a loss instead of a gain." 